\title{
New insight on the underdrawing of 16th Flemish-Portuguese easel paintings by combined surface analysis and microanalytical techniques
}

\author{
S. Valadas ${ }^{\mathrm{a}}$, R. Freire ${ }^{\mathrm{a}, \mathrm{b}}$, A. Cardoso ${ }^{\mathrm{a}}$, J. Mirão ${ }^{\mathrm{a}}$, P. Vandenabeele ${ }^{\mathrm{c}}$, J.O. Caetano ${ }^{\mathrm{d}}$, \\ A. Candeias ${ }^{\mathrm{a}, \mathrm{e}, *}$ \\ a Évora University, HERCULES Laboratory, School of Sciences and Technology, Largo Marquês de Marialva 8, 7000-809 Évora, Portugal \\ b Évora University, CHAIA-Centre for Art History and Artistic Research, Largo Marquês de Marialva 8, 7000-809 Évora, Portugal \\ c Ghent University, Archaeology Department, Sint-Pietersnieuwstraat 35, B-9000 Ghent, Belgium \\ d National Ancient Art Museum, General Directorate of Cultural Heritage, Rua das Janelas Verdes, 1300-001 Lisbon, Portugal \\ e Jose de Figueiredo Laboratory, General Directorate of Cultural Heritage, Rua das janelas verdes 37, 1300-001 Lisbon, Portugal
}

\section{A R T I C L E I N F O}

\section{Article history:}

Received 1 December 2015

Received in revised form 13 March 2016

Accepted 14 March 2016

Available online 17 March 2016

\section{Keywords:}

Underdrawing

Easel paintings

16th century portuguese-Flemish

workshop

Infrared surface exams

SEM-EDX

$\mu$-Raman spectroscopy

\begin{abstract}
A B S T R A C T
This paper focusses on the study of the underdrawings of 16th century easel paintings attributed to the workshop of the Portuguese-Flemish Master Frei Carlos. This investigation encompasses multidisciplinary research that relates the results of surface exams (infrared reflectography, standard light photography and infrared photography) with analytical investigations.

The surface analysis of Frei Carlos' underdrawings by infrared reflectography has shown heterogeneous work, revealing two different situations: (1) an abundant and expressive underdrawing, revealing a Flemish influence and (2) a simple and outlined underdrawing. This preliminary research raised an important question related to this Portuguese-Flemish workshop and to the analytical approach: Is the underdrawing's heterogeneity, as observed in the reflectograms, related to different artists or is this rather an effect that is produced due to the use of different materials in the underdrawing's execution? Consequently, if different materials were used, how can we have access to the hidden underdrawings? In order to understand the reasons for this dissemblance, chemical analysis of micro-samples collected in underdrawing areas and representing both situations were carried out by optical microscopy, micro Fourier transform infrared spectroscopy ( $\mu$-FTIR), scanning electron microscopy coupled with energy dispersive $X$-ray spectrometry (SEM-EDX) and micro-Raman spectroscopy ( $\mu$-Raman). Taking into account the different possibilities and practical and theoretical limitations of surface and punctual examinations in the study of easel painting underdrawings, the methodology of research was adjusted, sometimes resulting in a re-analysis of experimental results. This research shows the importance of combining multispectral surface exams and chemical analysis in the understanding of the artistic creative processes of 16th century easel paintings.
\end{abstract}

(c) 2016 Elsevier Ltd. All rights reserved.

\section{Introduction}

Underdrawings are the preliminary drawings on the panels (or canvas) and much of interest in this study lies in what they reveal about the creative processes of the artist, providing important information about workshops and developments in a certain time period (Bomford et al., 2002; Kammerer et al., 2007).

\footnotetext{
* Corresponding author at: Évora University, HERCULES Laboratory, School of Sciences and Technology, Largo Marquês de 8, Évora, Marialva, 7000-809, Portugal.

E-mail address: candeias@uevora.pt (A. Candeias).
}

Infrared reflectography has been the technique most widely used for revealing and studying underdrawings. Since its development in the late of 60s of the twentieth century by the Dutch physicist Van Asperen de Boer (Boer, 1968, 1970), the infrared reflectography technique has been an important tool for the in situ analysis and diagnosis of works of art (Faries, 2005), allowing to reveal the underdrawings under layers of paint through selective reflection/absorption of infrared radiation by the various constituent materials. Drawing, strokes, signatures, inscriptions, mechanical transfer processes, pentimenti and changes of composition hidden beneath layers of paint can be observed and revealed, allowing a deeper knowledge of the technique of an artist or 
workshop. Another important aspect concerns to the style of the underdrawing, whether the underdrawing is a simple sketch, freehand or rather methodical and orderly. Finally, another important issue concerns to the identification of the materials and drawing tools used in the creation of the underdrawing (Bomford et al., 2002; Fischer and Kakoulli, 2006; Kammerer et al., 2007; Candeias et al., 2011).

The nature of materials used in the underdrawings execution usually involves analytical research, which includes microsampling, microscopy observations and micro-analysis. It is not always possible to collect micro-samples and, even when it is possible, very small amounts of sample are obtained and even much smaller amounts of underdrawing material are available for analysis. Additionally, one has to take into account the fact that the underdrawing is located between paint layers and therefore one has to consider the nature of materials present in adjacent layers, which could not only hamper its visibility through infrared imaging tools but also they could compromise somehow the analytical data. On the other hand, a number of materials used to create underdrawing designs are based on some form of carbon and sometimes, even with a deeper chemical analysis, it is not possible to distinguish between them (Bomford et al., 2002). At this level, both surface analysis by infrared light and micro-analytical research should be complemented by each other, giving information on the response of the drawing materials at infrared light (e.g. visible or not visible, dry or fluid) and relating this to their optical properties and chemical composition (Bomford et al., 2002). More difficult is the identification of carbon and metal-based inks, as it has poor response in infrared reflectography. This hinders the micro-sampling process and also, due to the complexity of compounds that could be present (e.g. iron gall inks and respective gallatonate compounds), its chemical characterization. These seem to be the major reasons why very few, and extraordinary, analytical studies of these materials have been published (Dunkerton and Roy, 1986; Spring et al., 2009).

The characterization of the underdrawing in all those aspects could contribute, at the limit, to answer some questions related to the attribution and authentication of works of art.

This paper presents an extensive research based on the technical and material characterization of the underdrawing of sixteen century Portuguese-Flemish easel paintings attributed to Frei Carlos' Workshop.

Frei Carlos, one of the most important "Portuguese-Flemish Painters", working in the region of Évora (active between 1517 and 1539-40), left a large number of works that come mainly from the Espinheiro's Convent where he made the Profession of Faith (in 1517). "Portuguese-Flemish Painting" is a common expression used in the History of Portuguese art of the first third of the sixteenth century and in its most basic meaning it designates the work of Flemish Masters who settled in Portugal during the reign of King Manuel (1495-1521) contributing decisively to the process of renewal of Portuguese painting at the time (Santos, 1971). However, the designation surpasses this simple and objective perspective when it tends to transform it into a concept with higher operating interpretative ambitions, as for example, when it is suggested that such Flemish masters "adapted their work processes to the aesthetic concepts and spiritual climate prevailing in the workshops of the Portuguese masters, but without losing the qualities and technical skills acquired in the Flemish workshops where they did the learning" (Santos, 1971). Or, going further, when one considers that the "fusion of the characteristics of the two schools", Portuguese and Flemish, originated "a style, which is commonly called the Portuguese-Flemish" (Santos, 1971).

It is of utmost importance to do research that will deliver fundamental new data about the techniques of artistic production and the materiality of the works. Ultimately, it will allow us to identify possible similarities with works of Flemish painters of their time, opening up chances to determine the centres (Bruges, Ghent, Antwerp, or others) where they might have started their careers before arriving to Portugal and that the documental sources omit.

The first step to understand the Frei Carlos' workshop was the pioneering work of Couto (Couto, 1943) which based his attributions by combining visual examinations with surface exams, concluding that the technical and stylistic differences did not show changes in the way of painting of a single Master but instead were the result of collaboration of several officinal painters. A critical review of these arguments was later done by the Art Historian Seabra Carvalho (Carvalho, 1988-1993, 1998, 2006, 2011) which concluded that two types of pictorial preparatory drawing seemed to appear in the workshop creation, perhaps indicating a more complex internal structure. More recently, new data obtained by infrared reflectography confirm the heterogeneous creative process of this workshop and the need of a deeper resource based on the chemical composition of the materials (Candeias et al., 2011; Carvalho, 2013).

A deep investigation of this Master workshop and practices is being developed through multi-disciplinary teams combining historical research on documental sources with surface examination and material characterization using state-of-art analytical techniques. The results obtained so far highlight several similarities between Frei Carlos' workshop and Flemish schools, regarding materials and some particularities of the technique of artistic production (Valadas et al., 2013, 2014).

This investigation brings new perspective of the work attributed to this workshop, thought the technical and material characterization of the first sketch of an artist when he starts his work, the underdrawing.

\section{Materials and methods}

\subsection{Surface analysis}

The study of 16th Century Portuguese-Flemish paintings attributed to the Master Frei Carlos' workshop started with the visual examination of the paintings and surface exams, namely standard light photography, U.V. fluorescence photography, infrared reflectography, infrared photography and X-ray radiography.

Standard light photography was performed with a high resolution digital camera Nikon D3100 equipped with a CMOS sensor (DX format, 14.2 effective megapixel) and lenses AF-S DX zoom-Nikkor 18-55 mm f/3.5-5.6G ED II. Two lamps with tungsten light bulbs and $3200 \mathrm{~K}$ colour temperature were used to uniformly illuminate each of the paintings. The details were realized with a Nikon AF-S DX Micro Nikkor $40 \mathrm{~mm} \mathrm{f} / 2.8$ lens.

The reflectograms were obtained by using a high resolution infrared reflectography camera (Osíris) with an InGaAs detector allowing a wavelength response from 900 to $1700 \mathrm{~nm}$, and equipped with a $16 \times 16 \mathrm{~cm}^{2}$ tile system which allows an image size of $4096 \times 4096$ pixels. The camera comes with a longpass filter Schott RG850, allowing to transmit infrared wavelength and block the undesired shorter wavelength until $850 \mathrm{~nm}$. The reflectograms were performed for $45 \times 45 \mathrm{~cm}^{2}$ painting area.

Infrared photography was performed with a digital camera Nikon D3100 that was made sensitive to infrared radiation by removing the low-pass filter and operating with lenses AF-S DX Micro Nikkor $40 \mathrm{~mm} \mathrm{f/2.8G}$. The infrared radiation starts on the visible radiation limit above red till hertzian waves, from 730 to $10^{5} \mathrm{~nm}$ however, only a part can be registered by photography: the near infrared that goes till $1100 \mathrm{~nm}$. This system was also coupled with low-pass infrared filters X-Nite 780, 850 and $1000 \mathrm{~nm}$, 
Table 1

Analysis of the underdrawings in the paintings attributed to Frei Carlos workshop and his follower.

\begin{tabular}{|c|c|c|c|c|c|c|}
\hline \multirow{2}{*}{$\begin{array}{l}\text { Title of } \\
\text { painting/inventory } \\
\text { number }\end{array}$} & & \multirow[t]{2}{*}{ Date } & \multirow[t]{2}{*}{ Provenance } & \multicolumn{3}{|c|}{ Underdrawing identification } \\
\hline & & & & $\begin{array}{l}\text { Best response } \\
\text { area exams }\end{array}$ & Technique & Material \\
\hline \multirow[t]{3}{*}{ Anunciation } & MNAA 677 pint & Dated $1523^{a}$ & $\begin{array}{l}\text { St. Maria do Espinheiro } \\
\text { Monastery }\end{array}$ & IRR+IRP & FH: fluid media & $\mathrm{C}+\mathrm{IG}$ \\
\hline & & & & IRR & T: pouncing (brocade) & $\mathrm{C}$ \\
\hline & & & & $\mathrm{RX}$ & Metal-point & - \\
\hline $\begin{array}{l}\text { Mystic marriage of } \\
\text { Saint Catherine }\end{array}$ & MNAA 54pint & c. $1517-1538^{b}$ & $\begin{array}{l}\text { St. Maria do Espinheiro } \\
\text { Monastery (?) }\end{array}$ & IRR & FH: fluid media & C \\
\hline Three Saints & MNAA 174pint & c. $1517-1538^{b}$ & $\begin{array}{l}\text { St. Maria do Espinheiro } \\
\text { Monastery (?) }\end{array}$ & IRR & FH: fluid media & $\mathrm{C}$ \\
\hline $\begin{array}{l}\text { St. Francis receiving } \\
\text { the stigmata }\end{array}$ & MNAA 276pint & c. $1520-1530^{c}$ & Lóios Monastery & IRR & $\begin{array}{l}\text { FH: fluid media; } \\
\text { Dry drawing media }\end{array}$ & $\mathrm{C}$ \\
\hline $\begin{array}{l}\text { St. Anthony and the } \\
\text { Child }\end{array}$ & MNAA 64pint & c. $1520-1530^{c}$ & Lóios Monastery & IRR & FH: fluid media & C \\
\hline $\begin{array}{l}\text { St. Sebastian e St. } \\
\text { Vicent } \\
\text { (Follower of Frei } \\
\text { Carlos }^{\mathrm{d}} \text { ) }\end{array}$ & MNAA 100pint & c. $1530-1540 ?^{d}$ & $\begin{array}{l}\text { St. Vicente de Fora } \\
\text { Monastery }\end{array}$ & $\begin{array}{l}\mathrm{RX} \\
\text { IRR }\end{array}$ & $\begin{array}{l}\text { Metal-point } \\
\text { FH: fluid media; T: } \\
\text { pouncing (brocade) }\end{array}$ & - \\
\hline \multirow[t]{2}{*}{$\begin{array}{l}\text { Virgin with the Child } \\
\text { and an angel } \\
\text { (Follower of Frei } \\
\text { Carlos }^{\mathrm{d}} \text { ) }\end{array}$} & MNAA 58pint & c. $1530-1540 ?^{\mathrm{d}}$ & $\begin{array}{l}\text { St. Vicente de Fora } \\
\text { Monastery }\end{array}$ & IRR & $\begin{array}{l}\text { FH: fluid media; } \mathrm{T} \text { : } \\
\text { pouncing (brocade) }\end{array}$ & $\mathrm{C}$ \\
\hline & & & & $\mathrm{RX}$ & Metal-point & - \\
\hline \multirow[t]{2}{*}{$\begin{array}{l}\text { Appearance of Christ } \\
\text { to the Virgin }\end{array}$} & MNAA 2 pint & Dated 1529 & $\begin{array}{l}\text { St. Maria do Espinheiro } \\
\text { Monastery }\end{array}$ & $<\mathrm{IRR}$ & FH: fluid media & $\mathrm{C}+\mathrm{IG}$ \\
\hline & & & & $\mathrm{RX}$ & Metal-point & - \\
\hline Verónica & MNAA 51 pint & $\begin{array}{l}1 \text { st half of } 16 \text { th } \\
\text { century }\end{array}$ & $\begin{array}{l}\text { St. Maria do Espinheiro } \\
\text { Monastery }\end{array}$ & IRR & $\begin{array}{l}\text { FH:fluid media; } \mathrm{T} \text { : } \\
\text { pouncing (brocade) }\end{array}$ & C \\
\hline \multirow[t]{2}{*}{$\begin{array}{l}\text { Profession of St. } \\
\text { Paula }\end{array}$} & MNAA 85pint & $\begin{array}{l}1 \text { st half of } 16 \text { th } \\
\text { century }\end{array}$ & $\begin{array}{l}\text { St. Maria do Espinheiro } \\
\text { Monastery (?) }\end{array}$ & IRR & FH: fluid media & $\mathrm{C}$ \\
\hline & & & & $\mathrm{RX}$ & Metal-point & - \\
\hline $\begin{array}{l}\text { Assumption of the } \\
\text { Virgin }\end{array}$ & MNAA 82pint & $\begin{array}{l}\text { 1st half of } 16 \text { th } \\
\text { century }\end{array}$ & $\begin{array}{l}\text { St. Maria do Espinheiro } \\
\text { Monastery }\end{array}$ & IRP & FH: fluid media & $\mathrm{C}+\mathrm{IG}$ \\
\hline \multirow[t]{2}{*}{ Ascension of Christ } & MNAA 83pint & $\begin{array}{l}1 \text { st half of } 16 \text { th } \\
\text { century }\end{array}$ & $\begin{array}{l}\text { St. Maria do Espinheiro } \\
\text { Monastery }\end{array}$ & IRP & FH: fluid media & $\mathrm{C}+\mathrm{IG}$ \\
\hline & & & & IRR & $\mathrm{T}$ : pouncing (brocade) & $\mathrm{C}$ \\
\hline Ecce Homo & $\begin{array}{l}\text { MNAA } \\
\text { 2184pint }\end{array}$ & c. $1530^{\mathrm{a}}$ & Unknown & IRR & FH: fluid media & $\mathrm{C}$ \\
\hline \multirow[t]{2}{*}{ St. Brás } & ME1523 & c. $1520-1530^{\mathrm{d}}$ & $\begin{array}{l}\text { Santa Maria do } \\
\text { Espinheiro Monastery } \\
\text { (?) }\end{array}$ & $<$ IRR & FH: fluid media & $\mathrm{C}+\mathrm{IG}$ \\
\hline & & & & IRR & $\mathrm{T}$ : pouncing (brocade) & $\mathrm{C}$ \\
\hline St. Cristóvão & ME1524 & $\begin{array}{l}1 \text { st half of } 16 \text { th } \\
\text { century }\end{array}$ & $\begin{array}{l}\text { St. Maria do Espinheiro } \\
\text { Monastery (?) }\end{array}$ & $<$ IRR & $\mathrm{FH}$ & - \\
\hline \multirow[t]{2}{*}{ Nativity } & ME1525 & c. $1520-1525^{a}$ & $\begin{array}{l}\text { St. Maria do Espinheiro } \\
\text { Monastery }\end{array}$ & $<$ IRR & FH: fluid media; & $\mathrm{C}+\mathrm{IG}$ \\
\hline & & & & IRR & FH: Dry drawing media & C \\
\hline Lamentation & MNAA 74pint & c. $1530^{\mathrm{a}}$ & $\begin{array}{l}\text { St. Maria do Espinheiro } \\
\text { Monastery }\end{array}$ & IRR & $\begin{array}{l}\text { FH: fluid media; } \mathrm{T} \text { : } \\
\text { pouncing (brocade) }\end{array}$ & $\mathrm{C}$ \\
\hline \multirow[t]{3}{*}{ Good Shepherd } & MNAA 1 pint & c. $1520-1525^{a}$ & $\begin{array}{l}\text { St. Maria do Espinheiro } \\
\text { Monastery }\end{array}$ & IRP & FH: fluid media & $\mathrm{C}+\mathrm{IG}$ \\
\hline & & & & IRR & $\begin{array}{l}\text { FH: Dry drawing } \\
\text { media; } \\
\text { T: pouncing (brocade) }\end{array}$ & C \\
\hline & & & & $\mathrm{RX}$ & Metal-point & - \\
\hline Resurrection & MNAA 73pint & $\begin{array}{l}1 \text { st half of } 16 \text { th } \\
\text { century }\end{array}$ & $\begin{array}{l}\text { St. Maria do Espinheiro } \\
\text { Monastery }\end{array}$ & IRR+IRP & FH: fluid media & $\mathrm{C}+\mathrm{IG}$ \\
\hline $\begin{array}{l}\text { Virgin with a child } \\
\text { and two angels } \\
\text { (front) and Christ } \\
\text { Blessing (back) }\end{array}$ & $\begin{array}{l}\text { MNAA } \\
\text { 1179pint }\end{array}$ & $\begin{array}{l}1 \text { st half of } 16 \text { th } \\
\text { century }\end{array}$ & $\begin{array}{l}\text { St. Maria de Belém } \\
\text { Monastery }\end{array}$ & IRP & FH: fluid media & $\mathrm{C}+\mathrm{IG}$ \\
\hline \multirow[t]{2}{*}{ Calvary Triptych } & $\begin{array}{l}\text { MNAA } \\
\text { 2173pint }\end{array}$ & c. $1520-1530^{d}$ & $\begin{array}{l}\text { Quinta da Palmeira, } \\
\text { Seixal }\end{array}$ & IRR & FH: fluid media & $\mathrm{C}$ \\
\hline & & & & $\mathrm{RX}$ & Metal-point & - \\
\hline
\end{tabular}

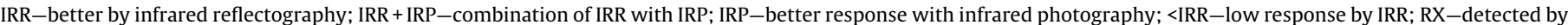
$\mathrm{X}$-ray radiography. $\mathrm{FH}$-freehand; T-Transfer process. C-carbon; IG-iron-gall ink; MP-metal-point.

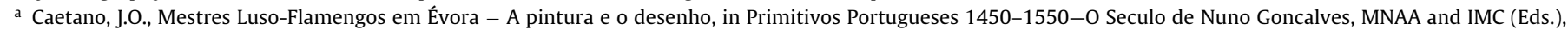
2011, pp. 276-293.

b Archival inventory database matriz net: www.matriznet.imc-ip.pt.

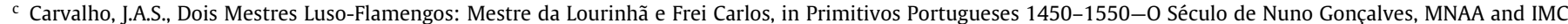
(Eds.), 2011, pp.156-173.

d Carvalho, J.A.S., 2013. O S. Vicente de Frei Carlos-estudo comparativo. Frei Carlos da América-Investigação e Crítica. MNAA. Lisboa, DGPC: 40-55. 

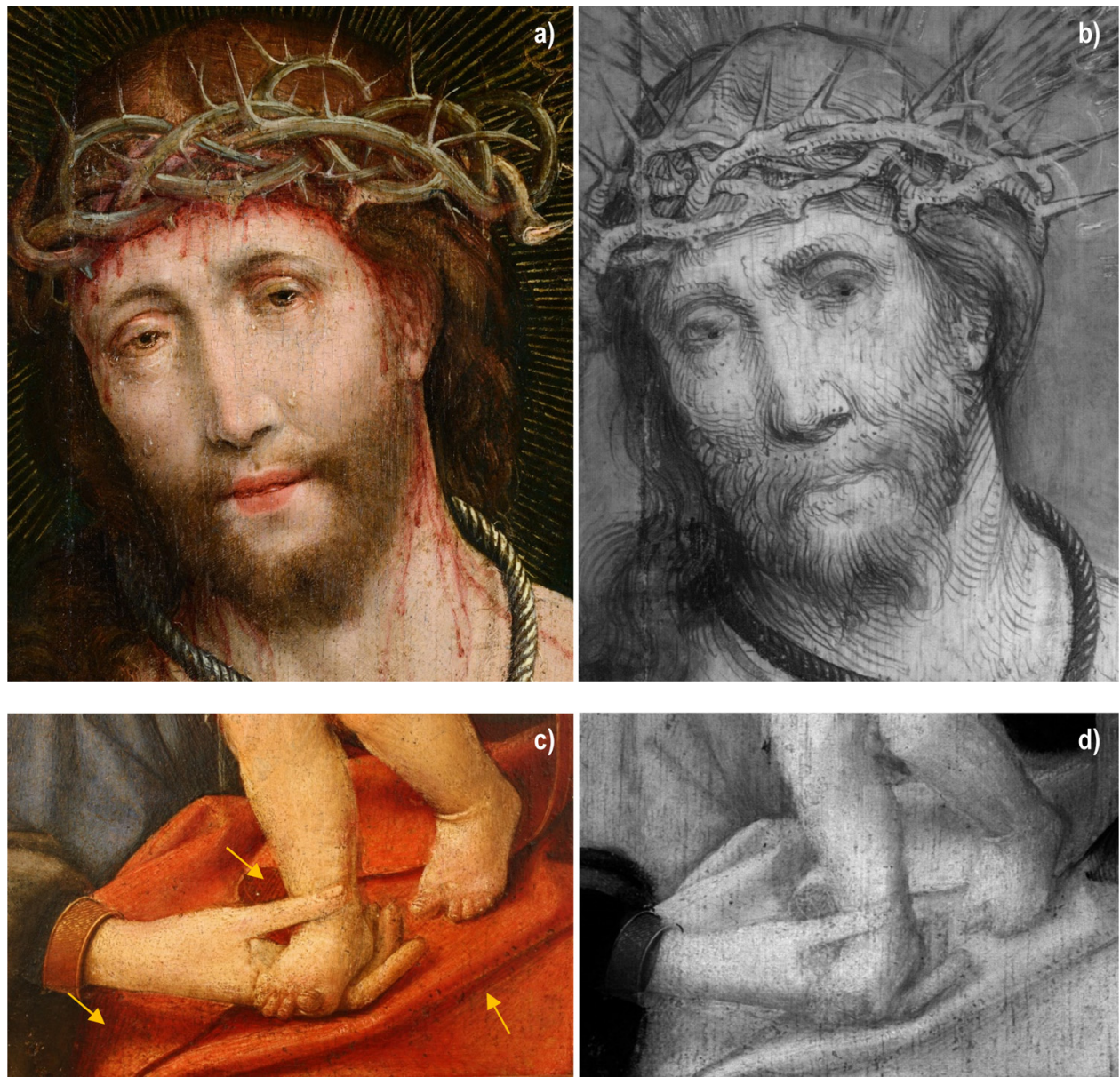

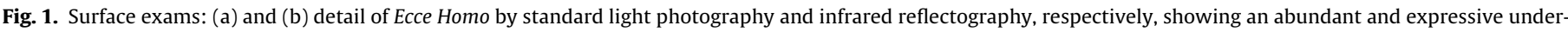

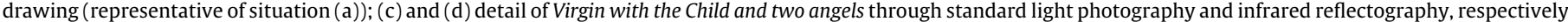

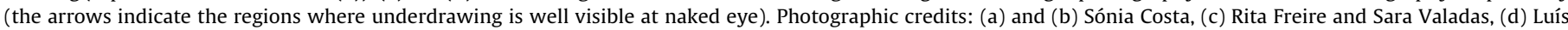
Piorro.

that block $50 \%$ of the infrared light and allows infrared light to pass until the limit of detection of the camera.

\subsection{Micro-analytical techniques}

This study encompasses the analytical and technical research of twenty one paintings attributed to Frei Carlos' workshop (see Table 1), focusing on the study of the underdrawings. The selection of representative underdrawing areas for microsampling was supported by imaging techniques. Microfragments were collected and mounted in epoxy resin in order to expose the paint layers for further analysis.

Optical microscopy observations $(\times 100$ and $\times 200$ magnifications) and the corresponding photographic documentation were obtained by a dark-field microscope (Leica DM2500, equipped with a Leica DFC 290HD camera).

Scanning electron microscopy coupled with energy dispersive X-ray spectroscopy (SEM-EDX) were carried out using a Hitachi S3700N scanning electron microscope coupled with a Bruker XFlash 5010 SDD detector. The samples (cross-sections) were analysed through low vacuum, at $40 \mathrm{~Pa}$ and the voltage used was $20 \mathrm{kV}$. This analytical setup allowed the identification of particles with different composition by combining electron backscattering imaging with EDS analysis, and also provided good quality X-ray compositional maps.

The Molecular analysis of underdrawing materials started with a Nexus ${ }^{\circledR} 670 \mu$-FTIR coupled to a Nicolet Continuum microscope by Thermo Nicolet, in the range $600-4000 \mathrm{~cm}^{-1}$, with an IR source, $\mathrm{KBr}$ beam splitter and a DMCT detector for MIR measurements, Individual sample layers were obtained by physical dissection and thin-sections were obtained by squeezing each sample between two diamond cells. For each sample 256 scans were recorded with a resolution of $4 \mathrm{~cm}^{-1}$

Cross-sections of underdrawing areas were analysed by a Horiba Xplora confocal micro Raman spectrometer, which is equipped with an Olympus BX41 camera and a CCD detector. The characterization of underdrawing materials was performed by using a $\mathrm{He}-\mathrm{Ne}$ laser operating at $785 \mathrm{~nm}$. Non-destructive analyses were ensured by combining density filters (maximum $10 \%$ ) and a $100 \times$ objective, resulting in a power at the sample of approximately $1 \mathrm{~mW}$.

\section{Results}

\subsection{Surface analysis}

Several historical and technical questions (Caetano, 2011; Carvalho, 2011, 2013) related to the characterization of the underdrawings in Espinheiroís workshop could be solved by extensive research based on the combination of standard light photography and infrared reflectography. Through the analysis of the paintings surfaces by naked eye, one can see that the underdrawing seems to be very abundant. This is clear on several areas such as carnations, light areas or damaged areas. However, the combined results obtained in this way revealed the following situations (Fig. 1): 


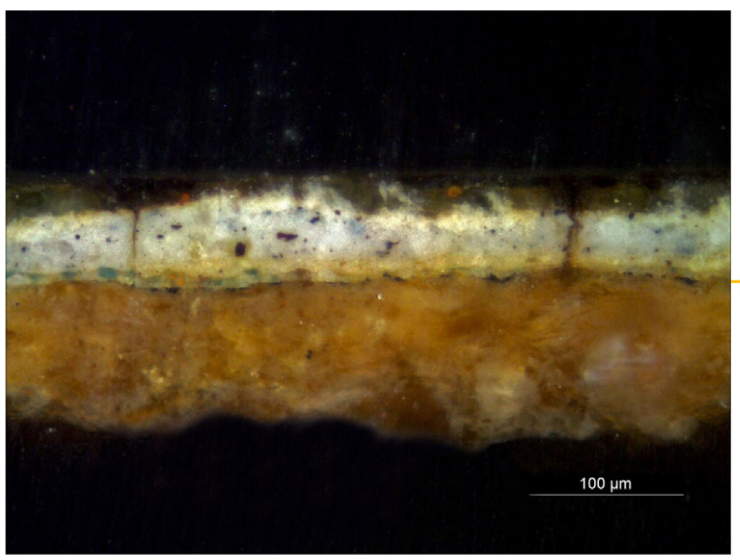

\begin{tabular}{|c|}
\hline - Underdrawing \\
applied directly over \\
the preparation \\
- Isolated particles of \\
a black material
\end{tabular}

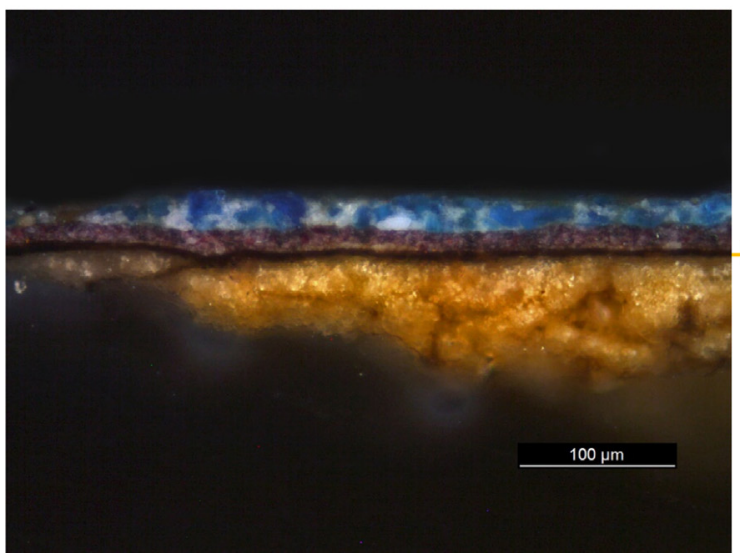

\begin{tabular}{|c|}
\hline - Underdrawing \\
applied directly over \\
the preparation \\
- Homogeneous and \\
regular layer of a \\
black / brown \\
material \\
\hline
\end{tabular}

Fig. 2. Optical microscopy of cross sections containing underdrawing, where (a) correspond to situation (c) and (b) illustrates situation (d).

a) In several paintings, infrared reflectography revealed an abundant and expressive underdrawing, pointing to the use of a wet medium. Sometimes it is also possible to see droplets at the ends of strokes, which seems to confirm this;

b) In other situations, although one can even see by naked eye hatched and cross-hatched underdrawing at the paintings surface, the reflectograms only revealed a thin and outlined underdrawing.

X-ray radiography and infrared reflectography have shown previously the existence of reserved areas, an abundant and expressive underdrawing present in several paintings and the lack of changes in composition that revealed how the work was meticulously planned. Considering this workshop practice, it was expected that similar work would be present in the other paintings attributed to the same workshop where the underdrawing is not detectable by infrared reflectography. Furthermore, previous studies (Billinge et al., 1997; Bomford et al., 2002; Finaldi and Garrido, 2006; Tamarit, 2006; Verri and Higgitt, 2010) developed on fifteen and sixteen century Flemish and Italian easel paintings indicate that when artists use non-carbonaceous-based inks, underdrawing is not visible or is poorly visible in infrared surface exams. A similar situation could be the reason for the unconformity of the data found, pointing to a material issue that can only be settled with supplementary analytical investigations.

\subsection{Microanalysis}

Concerning the underdrawing detection by infrared reflectography, two situations took place as mentioned before (situations (a) and (b)). The analytical study of these underdrawings relied on the data obtained by surface examinations and the possibility to col- lect microsamples in specific areas. The latter, however, is highly dependent on the museum context in which the paintings are and their state of conservation.

Due to the thinness of the underdrawing layers, analytical research started with the preparation of the micro-samples in cross-sections and dark field microscopical observation. The stratigraphic analysis revealed some optically distinguishable properties in the underdrawings layers (Fig. 2):

c) In most cases, the underdrawing layer appears as an irregular/not continuous line containing either isolated black particles or distinguished deposits of a black material applied over the preparation layer;

d) Sometimes, it is possible to distinguish a continuous and homegeous dark brown/black layer applied over the preparation layer, pointing to the use of a fluid material, corroborating the use of a wet technique.

By comparing all above situations we can suggest that when the underdrawing is well visible through infrared reflectography, it seems to be more likely to correspond to situation (c) and the black isolated or aglomerated particles should contain some carbonaceous material. Nevertheless, when the situation (d) occurs, it seems to correspond to those cases where the underdrawing is poorly/not visible by infrared reflectography (situation (b)), pointing to the use of a different material applied in a wet medium. Despite the mentioned correlations, sometimes it is hard to distinguish between them, since they are not exclusive from each other. On the other hand, the characterization of the underdrawing layers through optical properties lets us exclude the use of common materials such as some coloured chalks, as cited in literature (Bomford et al., 2002; Finaldi and Garrido, 2006). 

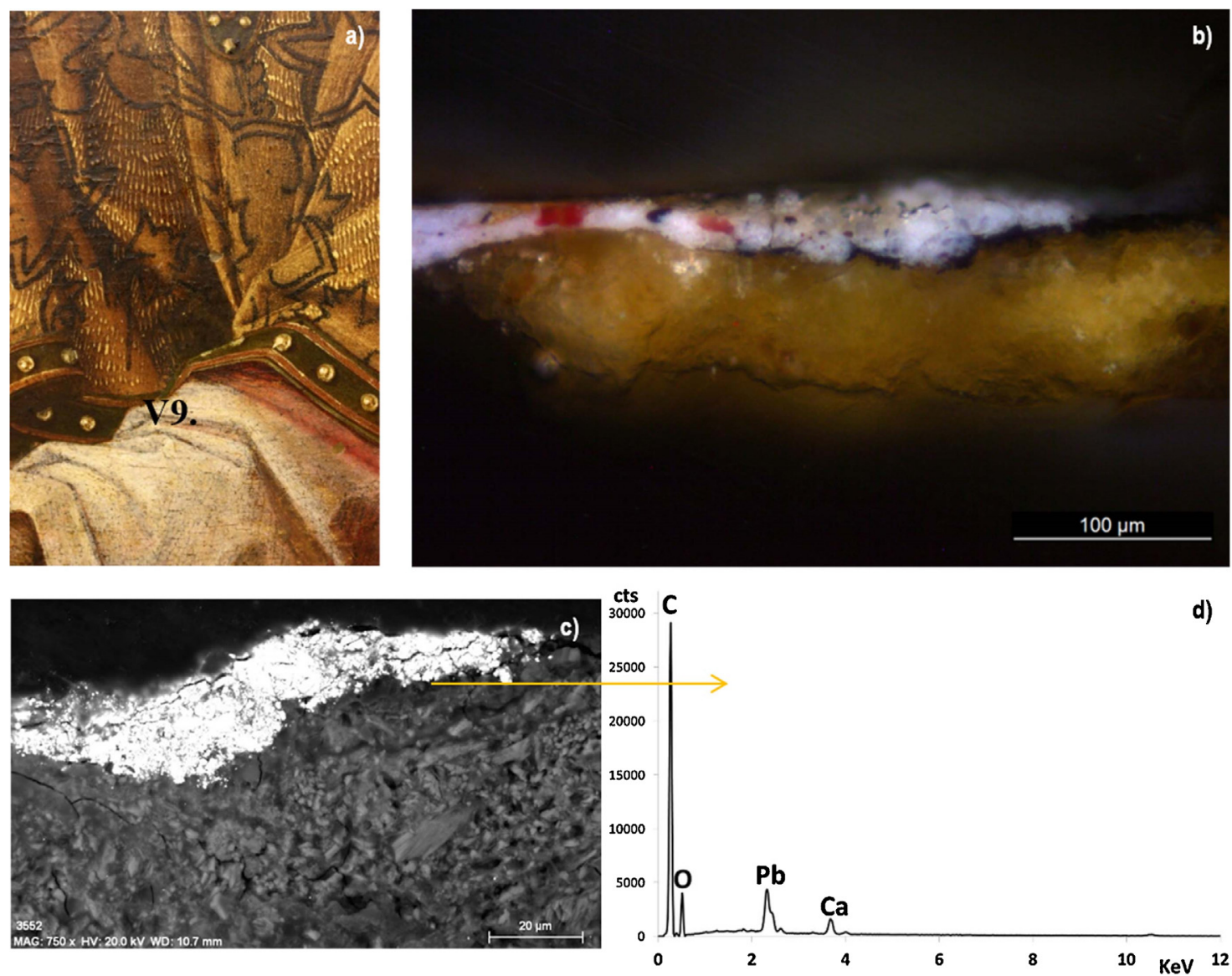

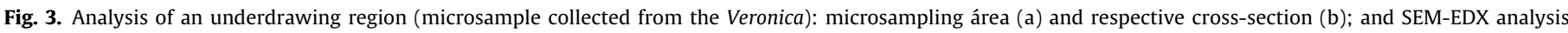
showing BSE image with indication of punctual EDX analysis (c) and the respective EDX spectrum of the underdrawing area (d).

In conclusion, although optical microscopy gave some clues about the technique and the nature of the materials used in the underdrawings execution it remains to answer which material is responsible for the invisibility of the underdrawing in situation (b). In this particular case, stratigraphic analysis also advanced a possible match of this material demonstrating that it seems to be applied in a wet medium and, taking into account, there is a high probabilility of the use of an iron gall ink (Campbell, 1998; Bomford et al., 2002).

Further analytical research was carried out in order to ascertain the nature of this material. Cross-sections representative for both situations and containing relatively high amounts of underdrawing material, were selected and submitted to SEM-EDX analysis, giving some indications about the nature of the materials used in the underdrawings execution.

Elemental analyses revealed the use of a carbon based material (probably carbon black) in paintings where the underdrawing is well visible by infrared reflectography (situation (a) see Fig. 3), as expected.

On the other hand, SEM-EDX analysis revealed an enrichment in iron (Fe) in the paintings where the underdrawing is not visible or is barely visible by infrared reflectography, related to situations (b), (Fig. 4). According to previous studies based on SEM-EDX analysis of easel paintingsí underdrawings (Dunkerton and Roy, 1986; Spring et al., 2009) we can propose the hypothesis of the use of iron gall ink. Besides the iron content, SEM-EDX analysis also revealed the presence of magnesium and aluminum as minor elements (Fig. 4g)) and sometimes it also revealed some traces of copper which, according to several studies on historical manuscripts, could be associated to iron sulphate contaminations in the ink formulation (Hahn et al.,
2004). Several studies (Camera, 2004; Hahn et al., 2004; Kolar et al., 2006) on the characterization of iron gall inks in historical manuscripts through elemental analysis (SEM-EDX and/or PIXE) also refer the possible presence of other elements such as zinc, manganese, sulfur, calcium, potassium, sodium, cobalt, nickel and silica. Although punctual analysis also points to the presence of calcium in the underdrawing area (Fig. 4c) and g)), one has to take the nature of nearby layers into consideration where this element could be present, e.g. the preparation layer consists of a calcium based material (e.g. calcite or gypsum)(Valadas et al., 2013), raising some dubiety about its presence as a contaminant of the ink.

Compositional elemental mappings also revealed a high content of carbon and oxygen in the underdrawing layers, suggesting an addition of an organic material, probably coming from the binding media used in the ink formulation. Moreover, this analytical technique also revealed in some cases the addition of noticeable isolated carbon particles to the iron based material, appearing partially mixed and pointing to a possible existence of a third material used by this workshop in the underdrawings execution.

Additionally, despite the presence of iron and copper in metalgall inks (Aceto et al., 2008), these elements can also occur as metal impurities in carbon-based inks. Although the metal concentration is often a good indicator of the metal source, full discrimination is only possible if complemented by molecular information about the ink organic/organometallic components (tannins and metalcomplexes). The infrared images of the paintings might suggest certain molecular species, but are not conclusive. The answer to these rising hypotheses can therefore be provided by techniques for structural analysis in the study of non-carbon-based underdrawings. 

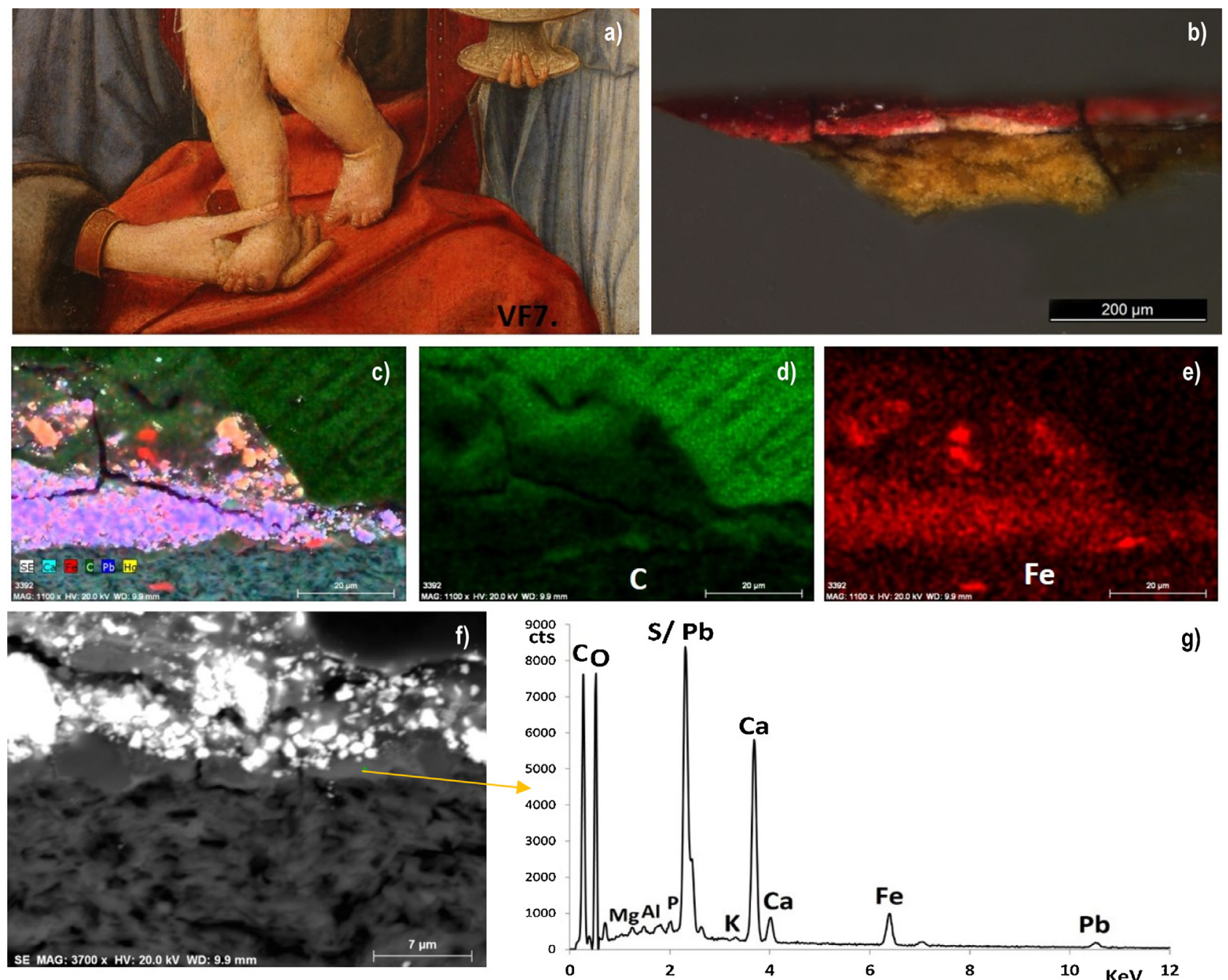

$\mathrm{S} / \mathrm{Pb}$

g)

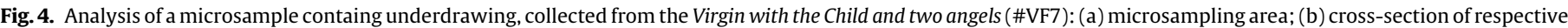

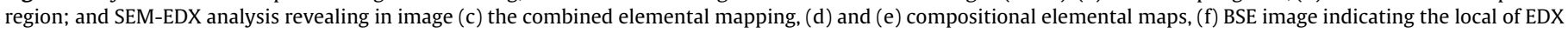
analysis and in $(\mathrm{g})$ the respective EDX spectrum of the underdrawing area.

FTIR experiments were performed in order to allow the assignment of characteristic absorption bands of functional groups associated to underdrawing areas.

$\mu$-FTIR analysis was performed in few paintings attributed to Frei Carlos' workshop where preparations are mainly composed by calcite, seeking to eliminate as much as possible the contaminations of sulfate groups present in the nearby gypsum preparations, found in most paintings (Valadas et al., 2013). The individual layers of underdrawing were obtained through dissection of the samples with a scalpel and the resulting thin sections were then analysed. Fig. 5 shows the wavelength assignments of underdrawing layers, evidencing the presence of $\mathrm{OH}$ vibrations in water molecules and the contributions of protein and oil mediums. Traces of calcium carbonate should also be considered and, although its presence here is not exclusive for underdrawing layers, this mineral and related oxalic compounds have frequently been found in iron gall ink composition (Ferrer and Sistach, 2005). Recorded spectra also display characteristic absorption bands, due to the 3 antisymmetric stretching vibrations in sulfate functional groups in the range $1300-1000 \mathrm{~cm}^{-1}$ and typical bending assignment, which occurs around $680-600 \mathrm{~cm}^{-1}$ (Derrick et al., 2000; Rouchon et al., 2012). The bands at $1109 \mathrm{~cm}^{-1}$ and $672 \mathrm{~cm}^{-1}$ are typical for anhydrite $\left(\mathrm{CaSO}_{4}\right)$, and are related to the $\nu 3$ antisymmetric stretch vibration and $v 4$ antisymmetric bending vibration, respectively. Anhydrite usually exhibits one weak band at $1015 \mathrm{~cm}^{-1}$ due to the $v 1$ symmetric stretch vibration modes of $\mathrm{SO}_{4}$ tetrahedras, but here it seems to be absent (Liu et al., 2009; Melo et al., 2014).

A previous study published by Espadaler et al. (Espadaler et al., 1995) has shown the presence of precipitated $\mathrm{CaSO}_{4}$ between paper fibers where iron gall ink had been applied and somehow our results point to a similar occurrence. In fact, several of the above mentioned studies refer the presence of calcium as an ink contaminant. Taking the acidic environment in which iron gall ink is formed and the ink's metal-sulfate additives into account (e.g. blue vitriol, $\mathrm{CuSO}_{4} \cdot 5 \mathrm{H}_{2} \mathrm{O}$, (Cennini, 1954; Hahn, et al., 2004; Chiavari et al., 2007) it is not surprising that some anhydrite could be present.

A more difficult assignment concerns to the occurrence of two bands at $1077 \mathrm{~cm}^{-1}$ and $1042 \mathrm{~cm}^{-1}$, still in the region of sulfate groups, pointing to a different sulfate based compound that could be possibly related to the presence of an iron sulfate material used in iron gall ink (Senvaitiene, 2006; Bicchieri et al., 2008a,b). However, when comparing the full range of assignments with the typical wavelengths of iron gall ink complexes, gallatonate compounds, gallic acid, pyrogallol or even gum arabic, it does not seem to reveal clear matches (Mohammed-Ziegler and Billes, 2002; Ursescu et al., 2009). The reasons for this absence can be related to the small quantity of sample available for analysis and also to the contribution of binding media and inorganic compounds (such as pigments) that 


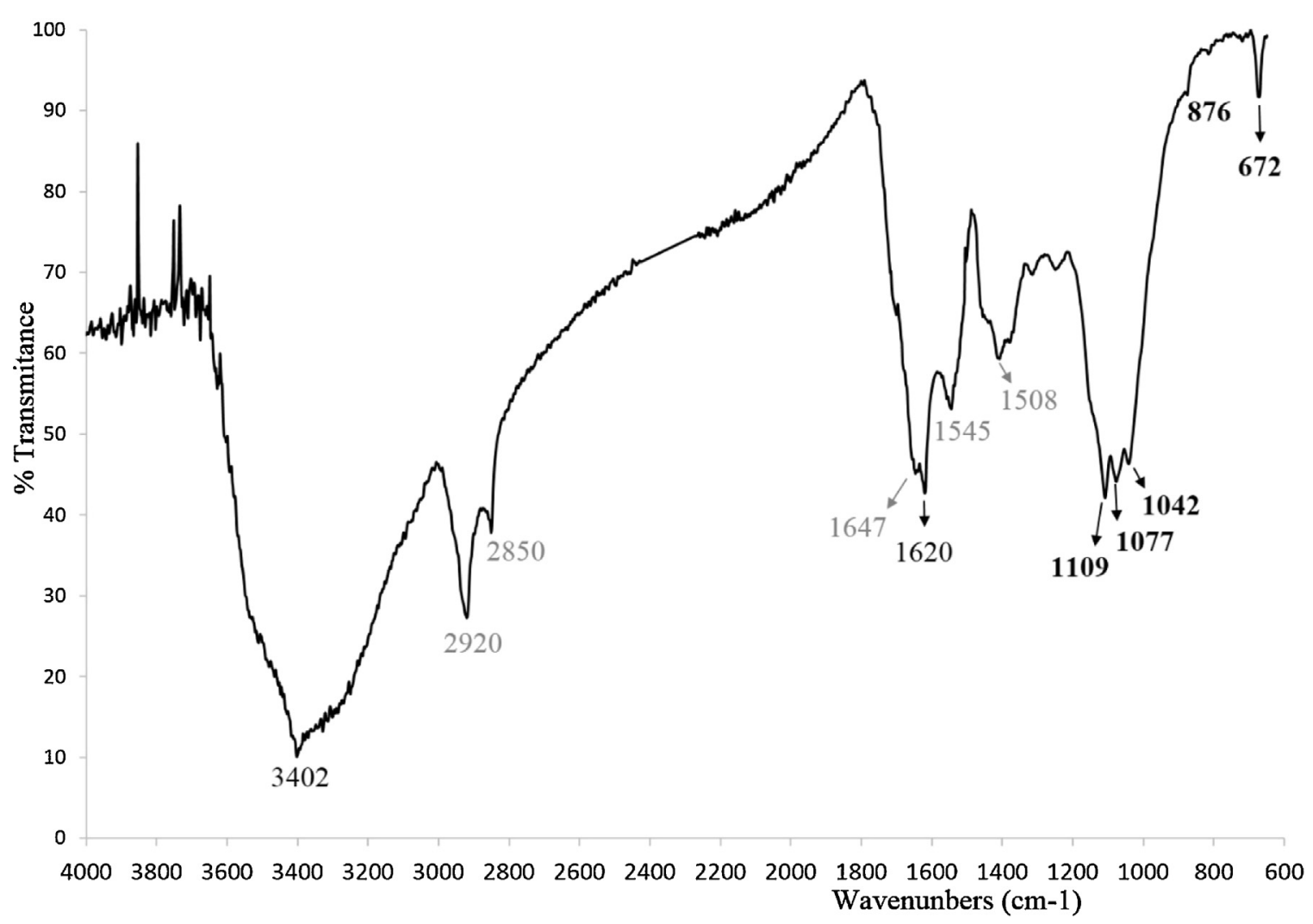

Fig. 5. Recorded FTIR spectrum of an underdrawing layer collected from a microsample of the Announciation (\#AN5).

could be present in the underdrawing areas and in adjacent layers, which may mask the typical spectral regions of these compounds.

$\mu$-FTIR analysis highlighted the occurrence of few functional groups frequently found in iron gall inks and related compounds although the presence of this underdrawing material could be no more than a merely hypothesis.

Complementary, $\mu$-Raman analysis was performed in several underdrawing areas and the spectra obtained in our work were compared with spectra obtained from previous studies developed in ancient manuscripts and papers, comercial iron gall inks and also with some experimental reprodutions according to ancient recipes (Brown and Clark, 2004; Vandenabeele and Moens, 2004; Lee et al., 2006, 2008; Chiavari et al., 2007; Aceto et al., 2008; Creagh et al., 2009).

Finally, a typical spectrum of iron gall ink was obtained and is shown in Fig. 6, revealing the four largest bands used as positive identification of this compound (Goltz, 2012). These occurred at $1468,1337,580$ and $528 \mathrm{~cm}^{-1}$ (combined broad band). While the band at $1468 \mathrm{~cm}^{-1}$ is characteristic of the iron-gall ink complex, the band that appears at $580 \mathrm{~cm}^{-1}$ has been associated to an iron-organic substrate complex/metallic salt and seems to be independent of the ink composition (Bicchieri et al., 2008a,b). Additionally, some recorded spectra also present a sharp band around $1012 \mathrm{~cm}^{-1}$, probably related to a residual presence of sulfate anions (Aceto et al., 2008). Sometimes traces of carbon black are also detected, suggesting that a carbon ink underdrawing material was also used by this workshop.

Although the obtained $\mu$-Raman spectra frequently presented poor resolution and weaker bands above a high fluorescence baseline, this technique allowed the confirmation of the use of iron gall ink by Frei Carlos' workshop and this is with no doubt the main result of this work. It also leads to the justification for the previous reported discrepancy, observed by infrared reflectography.
Additionally, SEM-EDX analysis also revealed an association of iron-based material to carbon particles, rising three main situations related to the materials used in the underdrawings:

- Underdrawing made with a carbon based material (probably in wet medium).

- Underdrawing executed with iron gall ink (wet medium).

- Underdrawing made with a mixture of iron gall ink and carbon (in a fluid process) or the reinforcement of iron gall ink material over the carbon underdrawing (as explained by Cennino Cennini in chapter CXXII, how the painters should draw on panel with charcoal, to begin with, and to fix it with ink (Cennini, 1954)).

Combining these results to surface analysis, we confirmed that when the underdrawing is executed with a carbon material, it is well visible by infrared reflectography as it was expected, but when the iron based material is present the infrared image is not visible or is barely visible, probably depending on the ratio iron gall ink:carbon (see Table 1).

\subsection{Surface analysis refinement}

Taking into consideration:

- the results that reveal the use of iron gall ink in this workshop, which has a poor response in infrared reflectography not allowing the characterization of underdrawing under these conditions;

- the recent studies based on DFT calculations using periodic boundary conditions on iron gall 3D coordination polymer which indicate that this compound has a maximum in its absorption spectrum at around $700 \mathrm{~nm}$ (Zaccaron et al., 2013a,b) and previous work on iron gall inks spectral absorption (Senvaitienè et al., 2005); 


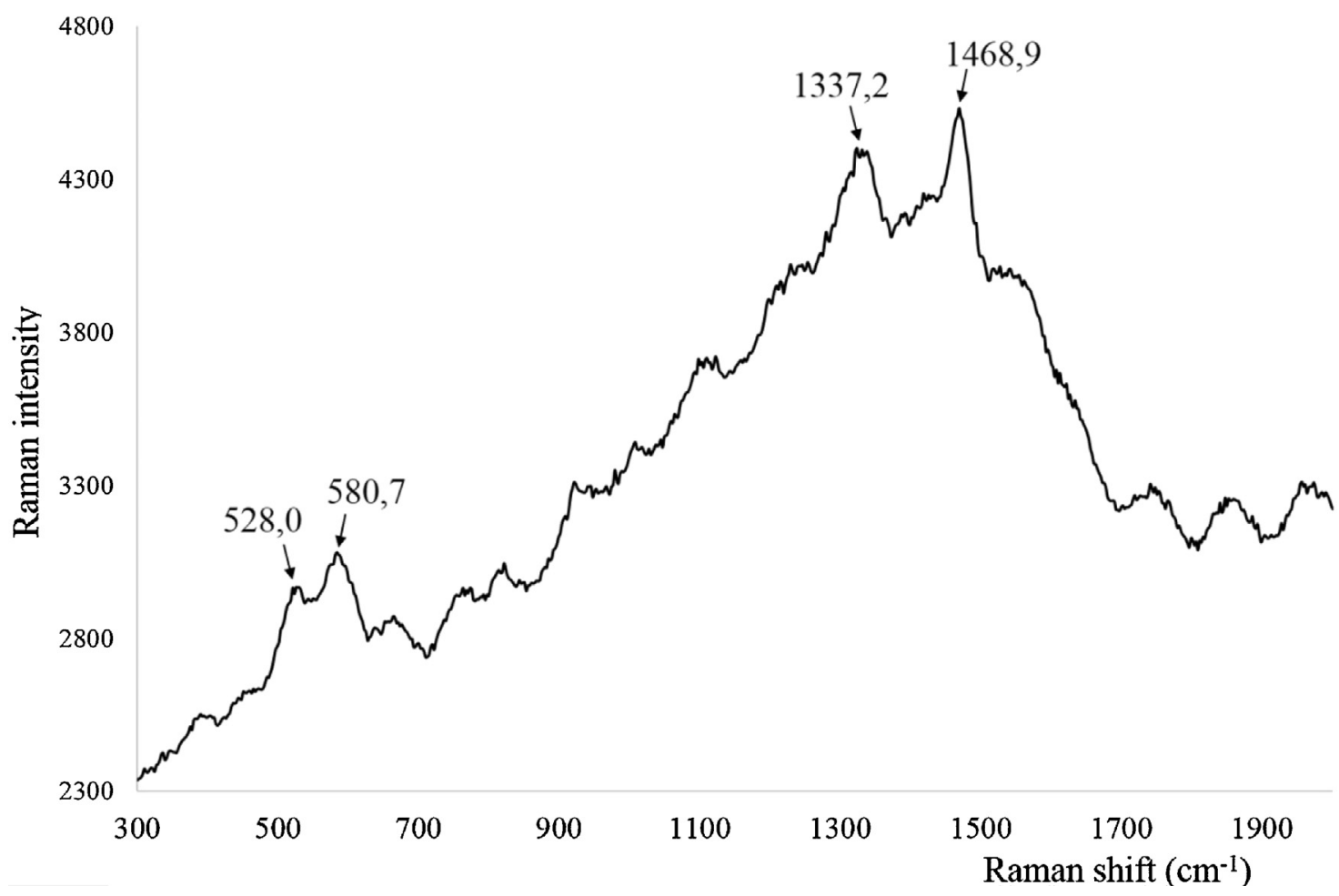

Fig. 6. Raman spectrum of iron gall ink (underdrawing layer collected from a microsample of the Good Shepherd, \#BP10).
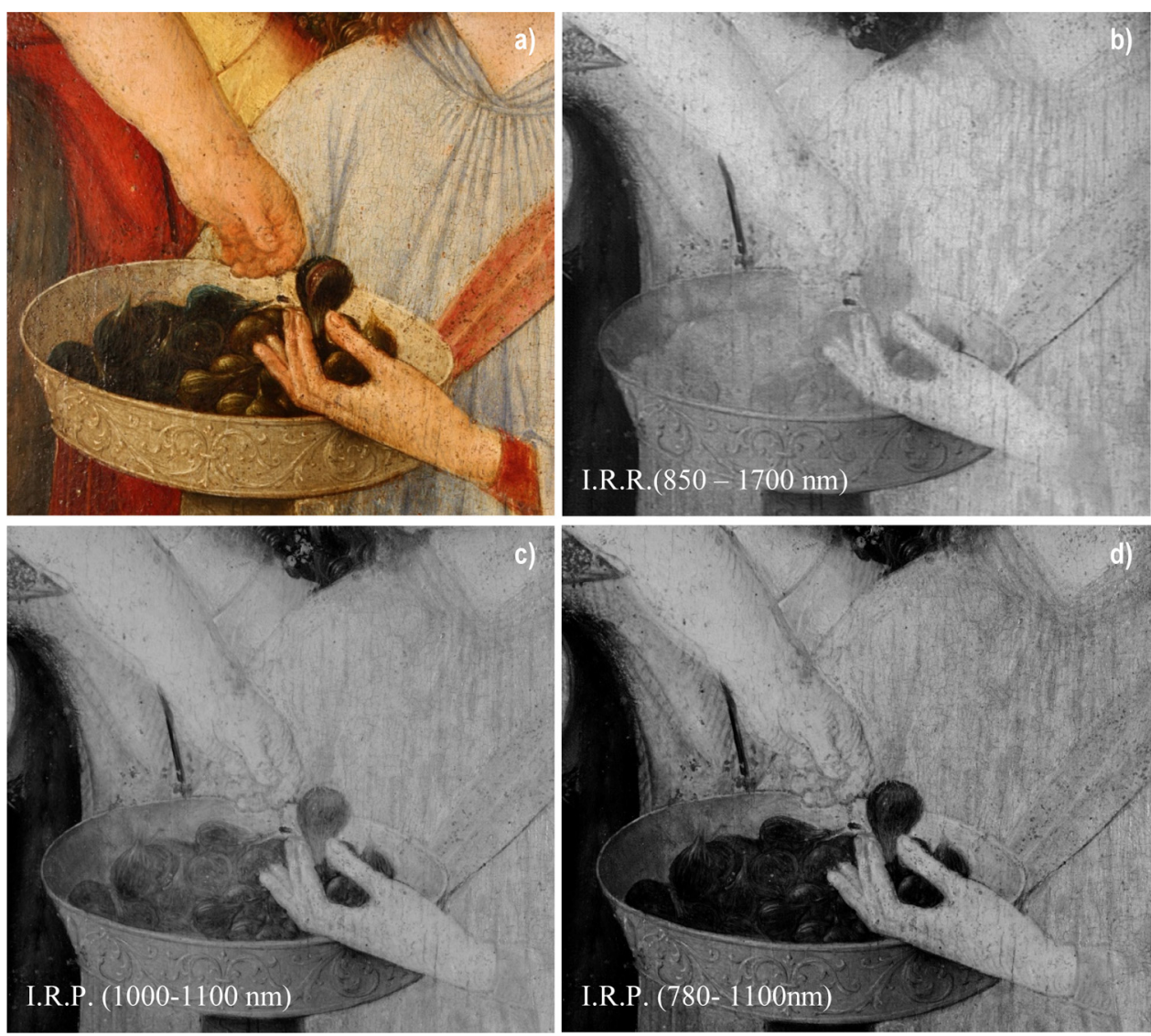

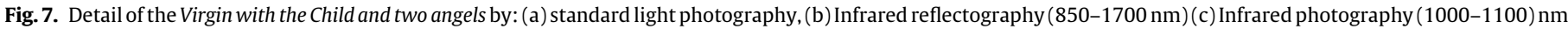
and (d) Infrared photography (780-1100 nnm). Photographic credits: (a) Rita Freire and Sara Valadas; (b), (c) and (d) Sara Valadas and Sónia Costa. 
- Previous studies based on multispectral and hyperspectral imaging technologies assessed on drawing inks (Baker, 1985; Kammerer et al., 2007) and easel paintings (Fischer and Kakoulli, 2006);

we decided to refine the surface analysis methodology to perceive this type of underdrawing. Therefore, to capture the underdrawing executed with this material that had not yet been revealed by infrared reflectography, we used several bandpass filters coupled to an infrared photographic camera.

The analysis of the painting surface with infrared reflectography and photography together with the analytical research, allowed us to conclude:

- In the paintings where a carbonaceous material was used for the underdrawing execution, infrared reflectography revealed an abundant underdrawing, better than infrared photography, as it was expected.

- For the paintings where iron gall ink was mostly used in the underdrawings execution, infrared photography revealed better results. (see Fig. 7). In these cases, the tests performed by infrared filters revealed a better signal for the $780 \mathrm{~nm}$ filter, probably due to the absorption of the Fe based material at lower wavenumbers.

Although IRR gave more information concerning carbon-based materials that absorb at higher wavelengths, sometimes a new analysis of paintings is needed by using lower infrared radiations, that could be useful to reveal underdrawings made with some iron gall ink.

\section{Conclusions}

This multianalytical and interdisciplinary study enabled a deeper insight on the work of Flemish-Portuguese 16th century painter Frei Carlos by revealing the use of iron-gall ink in the underdrawing of several paintings. This is particularly relevant because although historic documental sources refer to the use of iron gallinks from about the third century BC and although some studies on 15 th and 16 th century easel paintings have pointed out its possible use in underdrawing, it is the first time that it has been unequivocally identified in 16th century easel painting.

Furthermore, it allowed us to explain the previous discrepancies on the underdrawing of this Master workshop that were pointed out by art historians through observation of IR reflectographies, concluding that this Master had two types of underdrawing: a very strong and marked underdrawing in opposition to a very light and almost imperceptible one. It is now clear that these discrepancies are due to a choice in materials (charcoal and/or iron-gall ink) rather than a different technical or stylistic approach.

This study points out for the need of developping more advanced methodologies in the study of underdrawing, particularly when no signal or weak response is given by IR reflectography. For iron-gall ink underdrawing, the best results are obtained by IR photography at lower wavelenghts.

This research could also lead to the refinement of methodologies and techniques of examination for underdrawing studies.

\section{Acknowledgements}

The authors wish to acknowledge the Fundação para a Ciência e Tecnologia (Portuguese Science and Technology Foundation) for financial support (PhD grant SFRH/BD/66068/2009 and project ONFINARTS - PTDC/EAT-HAT/115692/2009) through program QREN-POPH-typology 4.1., co-participated by the Social European Fund (FSE) and MCTES National Fund. The authors wish to thank to the HERCULES Lab and José de Figueiredo Lab teams for all scientific collaboration particularly, Sonia Costa and Luis Piorro for aiding in the surface exams. The authors also wish to thank to the Évora Museum and National Ancient Art Museum (Lisbon) for granting access to the paintings and its staff, in particular to art historians José Alberto Seabra and Joaquim Caetano for art history collaboration and conservators Susana Campos and Teresa Moura for technical support during paintings handling and analysis.

\section{References}

Aceto, M., Agostino, A., et al., 2008. The Vercelli Gospels laid open: an investigation into the inks used to write the oldest Gospels in Latin. X-ray Spectrom. 37 (4), 286-292.

Baker, C.A., 1985. A comparison of drawing inks using ultraviolet and infrared light examination techniques. In: Application of science in examination of works of art: proceedings of the seminar, September 7-9, 1983, Museum of Fine Arts.

Bicchieri, M., Monti, M., et al., 2008a. All that is iron-ink is not always iron-gall! J. Raman Spectrosc. 39 (8), 1074-1078.

Bicchieri, M., Monti, M., et al., 2008b. Inside the parchment. In: 9th International Conference on NDT of Art, Jerusalem, Israel.

Billinge, R., Dunkerton, L.C.J., Foister, S., Kirby, J., Pilc, J., Roy, A., Spring, M., White, R., 1997. Methods and Materials of Northern European Painting in the National Gallery, 1400-1550. National Gallery Technical Bulletin. National Gallery Publications Limited, London, pp. 6-55.

Boer, V.A.d., 1968. Infrared reflectography: a method for the examination of paintings. Appl. Opt. 7 (9), 1711-1714.

Boer, V.A.d., 1970. Infrared reflectography: a contribution to the examination of earlier European paintings, Universiteit van Amsterdam Doctoral dissertation.

Bomford, D., Billinge, R., et al., 2002. Art in the Making-Underdrawings in Renaissance Paintings. National Gallery London, London.

Brown, K.L., Clark, R.J.H., 2004. The Lindisfarne Gospels and two other 8th century Anglo-Saxon/Insular manuscripts: pigment identification by Raman microscopy. J. Raman Spectrosc. 35 (1), 4-12.

Caetano, J.O., 2011. Mestres Luso - Flamengos em Évora-A pintura e o desenho. Primitivos Portugueses 1450-1550-O Século de Nuno Gonçalves. MNAA and IMC, Lisboa, pp. 276-293.

Camera, D.L., 2004. An Investigation into the Prevalence \& Chemistry of Crystal Formations on the Surface of Iron Gall Ink: The Preliminary Results. Book \& Paper Group(23), pp. 75-86.

Campbell, L., 1998. The fifteenth century Netherlandish paintings. In: National Gallery Catalogues. National Gallery company, N. Gallery. London, pp. 30.

Candeias, A., Piorro, L., Valadas, S., Dias, C., Mirão, J., 2011. Não há de encoberto que não venha a ser descoberto, nem de oculto que não venha a ser revelado. Considerações sobre a técnica de reflectografia de infravermelhos. Primitivos Portugueses 1450-1550-O Século de Nuno Gonçalves. MNAA and IMC, Lisbon, pp. 294-298.

Carvalho, J.A.S., 1988-1993. Pintura luso-flamenga em Évora no início do século XVI. O Mestre da Lamentação da Oficina do Espinheiro. A Cidade de Évora. Évora, Câmara Municipal de Évora, pp. 75-104.

Carvalho, J.A.S., 1998. Frei Carlos e o outro. Proposições sobre a pintura da Oficina do Espinheiro. Do Mundo Antigo aos Novos Mundos. Humanismo, Classicismo e notícias dos Descobrimentos em Évora 1516-1624. Lisboa, Comissão Nacional para as Comemorações dos Descobrimentos Portugueses.

Carvalho, J.A.S., 2006. Frei Carlos pintor no Convento. Convento do Espinheiro, Memória e Património. SPPTH.

Carvalho, J.A.S., 2011. Dois Mestres Luso-Flamengos: Mestre da Lourinhã e Frei Carlos. Primitivos Portugueses 1450-1550-O Século de Nuno Gonçalves. MNAA and IMC. Lisboa, pp. 156-173.

Carvalho, J.A.S., 2013. O S. Vicente de Frei Carlos-estudo comparativo. Frei Carlos da América-Investigação e Crítica. MNAA. Lisboa, DGPC, pp. 40-55.

Cennini, C.d.A., 1954. The Craftsman's Handbook: Il Libro dell' Arte. Dover Publications Inc., New York.

Chiavari, G., Montalbani, S., et al., 2007. Application of analytical pyrolysis for the characterisation of old inks. J. Anal. Appl. Pyrolysis 80 (2), 400-405.

Couto, J., 1943. A pintura flamenga em Évora no século XVI. Variedade de estilos e de técnicas na obra atribuída a Frei Carlos. Cidade de Évora. Évora, Câmara Municipal de Évora.

Creagh, D., Lee, A., et al., 2009. Recent and future developments in the use of radiation for the study of objects of cultural heritage significance. Radiat. Phys. Chem. 78 (6), 367-374.

Derrick, M.R., Stulik, D., et al., 2000. Infrared Spectroscopy in Conservation Science. Getty Publications.

Dunkerton, J., Roy, A., 1986. The Technique and Restoration of Cima's T̈he Incredulity of S. Thomas: National Gallery Technical Bulletin, 10. Order of the Trustees, London, pp. 4-27.

Espadaler, I., Sistach, M., et al., 1995. Organic and inorganic components of manuscript inks. Anal. Quimica, c1996-c1997, Barcelona, Spain Springer-Verlag Iberica.

Faries, M., 2005. Analytical capabilities of infrared reflectography: an art historian's perspective. In: Scientific Examination of Art: Modern Techniques in Conservation and Analysis. The National Academies Press, pp. 87-104. 
Ferrer, N., Sistach, M.C., 2005. Characterisation by FTIR spectroscopy of ink components in ancient manuscripts. Restaurator 26 (2), 105-117.

Finaldi, G., Garrido, C., 2006. El trazo oculto. Dibujos subyacentes en pinturas de los siglos XV y XVI. Madrid Museo Nacional del Prado.

Fischer, C., Kakoulli, I., 2006. Multispectral and hyperspectral imaging technologies in conservation: current research and potential applications. Stud. Conserv. 51 (Suppl. 2), 3-16.

Goltz, D.M., 2012. A review of instrumental approaches for studying historical inks. Anal. Lett. 45 (4), 314-329.

Hahn, O., Malzer, W., et al., 2004. Characterization of iron-gall inks in historical manuscripts and music compositions using X-ray fluorescence spectrometry. X-ray Spectrom. 33 (4), 234-239.

Kammerer, P., Lettner, M., et al., 2007. Identification of drawing tools by classification of textural and boundary features of strokes. Pattern Recognit. Lett. 28 (6), 710-718.

Kolar, J., Štolfa, A., et al., 2006. Historical iron gall ink containing documents-properties affecting their condition. Anal. Chim. Acta 555 (1) 167-174.

Lee, A.S., Mahon, P.J., et al., 2006. Raman analysis of iron gall inks on parchment. Vib. Spectrosc. 41 (2), 170-175

Lee, A.S., Otieno-Alego, V., et al., 2008. Identification of iron-gall inks with near-infrared Raman microspectroscopy. J. Raman Spectrosc. 39 (8) 1079-1084.

Liu, Y., Wang, A., et al., 2009. Raman, MIR and NIR spectroscopic study of calcium sulfates; gypsum, bassanite, and anhydrite Lunar and Planetary Science Conference, Texas.

Melo, H.P., Cruz, A.J., et al., 2014. Problems of analysis by FTIR of calcium sulphate-based preparatory layers: the case of a group of 16th-century Portuguese paintings. Archaeometry 56 (3), 513-526.

Mohammed-Ziegler, I., Billes, F., 2002. Vibrational spectroscopic calculations on pyrogallol and gallic acid. J. Mol. Struct. THEOCHEM 618 (3), 259-265.

Rouchon, V., Badet, H., et al., 2012. Raman and FTIR spectroscopy applied to the conservation report of paleontological collections: identification of Raman and FTIR signatures of several iron sulfate species such as ferrinatrite and sideronatrite. J. Raman Spectrosc. 43 (9), 1265-1274.
Santos, A.V., 1971. Pintura Luso-Flamenga. Dicionário de Pintura Universal, Pintura Portuguesa. E. Cor. Lisboa. III.

Senvaitienè, J., Beganskienè, A., et al., 2005. Characterization of historical writing inks by different analytical techniques. Chemija 16 (3-4), 34-38.

Senvaitiene, J., 2006. Analytical identification of historical writing inks-a new methodological approach. Lithuanian J. Phys. Tech. Sci. 46, 109-115.

Spring, M., Daniilia, S., et al., 2009. Underdrawing, ground/priming layers. Scientific Examination for the Investigation of Paintings: A Handbook for Conservator-Restorers. Daniela Pina, Monica Galeotti and R. Mazzeo. Florence, Centro Di.

Tamarit, P.I., 2006. El conocimiento del soporte y del dibujo subyacente por medio de la radiografía y reflectografía de infrarrojo Los retablos: Técnicas, materiales y procedimientos. G. E. d. IIC. España.

Ursescu, M., Malutan, T., et al., 2009. Iron gall inks influence on papers thermal degradation. FTIR spectroscopy applications. Eur. J. Sci. Theol. 5 (3), 71-84.

Valadas, S., Cardoso, A., et al., 2013. A Pintura Flamenga em Évora no século XVI novas perspectivas sobre a obra atribuída a Frei Carlos. As preparações na Pintura Portuguesa Séculos XV e XVI. F. d. L. d. U. d. Lisboa. Museu Nacional de Arte Antiga, Lisboa, Portugal, PPP Séculos XV \& XVI: 115-122.

Valadas, S., Freire, R., et al., 2014. On the use of the unusual green pigment Brochantite $\left(\mathrm{Cu}_{4}\left(\mathrm{SO}_{4}\right)(\mathrm{OH})_{6}\right)$ in the 16 th century Portuguese-Flemish paintings attributed to the Master Frei Carlos workshop. Microsc. Microanal. 21 (2), 518-525.

Vandenabeele, P., Moens, L., 2004. Pigment Identification in Illuminated Manuscripts. Elsevier, Amsterdam, pp. 635.

Verri, G., Higgitt, S.T.C., 2010. Inks and washes. In: Higgitt, Catherine, Ambers, Janet, Saunders, David (Eds.), Italian Renaissance Drawings: Technical Examination and Analysis. Archetype Publications, The British Museum.

Zaccaron, S., Ganzerla, R., et al., 2013a. Iron complexes with gallic acid: a computacional study on coordination compounds of interest for the preservation of cultural heritage. J. Coord. Chem. 66 (10), 1709-1719.

Zaccaron, S., Ganzerla, R., et al., 2013b. DFT calculations using periodic boundary conditions on an iron gall 3D coordination polymer of interest for cultural heritage conservation. Sciences at Ca'Foscari. (1| 2013). 